\title{
New concepts in alloimmune recognition
}

\author{
Jeffrey L. Platt* \\ Transplantation Biology Program and the Departments of Immunology, Surgery, and Pediatrics \\ Mayo Clinic College of Medicine, Rochester, MN 55905, USA
}

\section{Introduction}

No field of biological experimentation or medical practice has provoked more interest and excitement and few have generated more fundamental knowledge than the field of transplantation. Reactions to transfusion of blood provided the first compelling evidence of genetic differences in humans [1]. The successful transplantation of the kidney taught that organs and tissues can function independent of their position in the body, but also warned that such transplants faced a daunting biological barrier, the nature of which was unclear $[2,3]$. The acceptance of grafts was found to depend on genetic traits [4,5], which could be shown to be inherited as polyallelic, co-dominant genes that could be mapped to a chromosomal locus [6]. At the same time, transplantation could be shown to generate immunity [7], although whether immunity accounted for failure of grafts was less certain. Ultimately, the careful analysis of one human subject given skin grafts for the treatment of extensive burns showed that the barrier to transplantation is indeed related to the immune response transplantation provokes [8].

Much of the excitement of transplantation, however, is distinct from the lessons transplantation teaches. Transplantation has offered the prospect of replacing organs and tissues in disease for those conditions for which specific therapies or spontaneous recovery do not suffice. One might argue that knowledge about transplantation immunology is so complete and immunosuppressive drugs are so effective that little of importance remains to be learned. This view, however, is defied by dramatic and indeed accelerating advances in the theory and practice of transplantation. The papers presented in this symposium provide examples of those advances, and more importantly, point to questions of importance yet to be addressed.

Essential to the mounting of effective defenses against infecting organisms is the sparing of autogenous cells from inadvertent injury. Ehrlich appreciated this challenge when, considering whether auto-antibodies might be formed and might act, he wrote in 1900: “...that in an individual who has had an extensive haemorrhage into a body-cavity, that the absorbtion of this blood would cause the formation of a blood poison [auto-antibody] which would destroy the rest of the blood-cells would be difficult for anyone to believe..." [9]. One hundred years later, we understand much about how immunity protects against infectious threats but less than we might about how infected tissues are spared from injury. In no realm is this question more keenly felt than in the field of transplantation. Transplanted organs and tissues engender a potent immune response rather than tolerance [10], and most complications of transplantation reflect alloimmunity that is incompletely controlled or injury to organs, especially the heart,

\footnotetext{
Work in the author's laboratory is supported by grants from the National Institutes of Health (HL79067, HL52297).

*Fax: (507)284-4957, Platt.jeffrey@mayo.edu.

Publisher's Disclaimer: This is a PDF file of an unedited manuscript that has been accepted for publication. As a service to our customers we are providing this early version of the manuscript. The manuscript will undergo copyediting, typesetting, and review of the resulting proof before it is published in its final citable form. Please note that during the production process errors may be discovered which could affect the content, and all legal disclaimers that apply to the journal pertain.
} 
caused either by non-specific products of immunity (cytokines) or by complications of immunosuppressive drugs.

The immune system is generated in part by selection. Lymphocytes are selected for nonresponsiveness to "self." However, selection does not avert auto-reactivity. In fact, T cells must recognize self or they die. Accordingly, inadvertent injury must be avoided by other means. Thus, immune regulation engenders acquired non-responsiveness to self. But, if acquired nonresponsiveness is so powerful, why does allorecognition lead inexorably to rejection rather than tolerance?

The papers composing this symposium address the questions of how elements of the immune system recognize and respond to transplants. As the remarks above suggest, these two questions were the first to be asked and some might think the answers are settled. However, the papers in this symposium show that revisiting what we think we know can yield some new and surprising insights of the greatest importance.

The response of the T cell compartment to foreign antigens demonstrates the classic elements of adaptive immunity- $\mathrm{T}$ cell responses are specific, are systemic, and exhibit memory. In fact, what might be taken as the first unequivocal evidence that immunity causes the rejection of transplants can, in retrospect, be ascribed to T cell responses to skin allografts. Thus, Gibson and Medawar [8] found that whereas autologous skin engrafts and survives indefinitely when placed on a burn wound, allogeneic skin engrafts, but then over a period of days, the skin deteriorates and sloughs, thus illustrating specificity and generality. When a second set of grafts from the same donor was placed, injury to the allograft was far more rapid, thus illustrating memory. Although immunologists initially ascribed this allograft reaction to humoral immunity, tissue grafts are now known to be rejected predominantly by cellular and not humoral immunity [11].

Seeming to contradict these seminal concepts of transplantation biology, Huang and Rabb [12] have found that $\mathrm{T}$ cells can also mediate the very rapid injury that is associated with ischemia reperfusion of organs, as described in their review. The extent to which this T-cellmediated injury exhibits specificity and memory is still uncertain. Yet, clearly, envisioning potential involvement of $\mathrm{T}$ cells in innate immune responses constitutes an entirely new field of endeavor in immunology.

Another classical question in immunology is how the fetus avoids destruction as a semiallogeneic graft [13]. Some have ascribed self-tolerance to a process of learning that occurs during development [14], and the developmental aspects of the immune response led to the earliest successful efforts to deliberately induce allogeneic tolerance [15]. However, developmental events cannot explain how the mother fails to reject the semi-allogeneic fetus, since paternal antigens were presumably first presented in adulthood. Nor does developmental immunology explain how repeated pregnancies and allosensitization predict better, rather than worse, success in subsequent pregnancies. In this symposium, Cody Koch and I [16] consider the various mechanisms that may allow survival of the fetal graft, and stress that the central challenge to immunology of this graft remains.

Improvements in immunosuppression have made rejection of allografts a relatively infrequent event in clinical transplantation. Still, successful control of cellular immunity has highlighted humoral rejection as the preeminent challenge in transplantation. Humoral rejection initiated by alloreactive antibodies, and hence called antibody-mediated rejection, is not always mediated by antibodies and usually requires the action of complement. Complement provides a critical effector of injury, mainly by targeting endothelial cells, but may also help control immune responses. In their review paper, Wasowska and Baldwin [17] explain how 
complement is recruited to do so, and in this sense they explain how the complement system recognizes allogeneic tissues.

As much as developmental events may contribute tolerance by deletion of potentially autoreactive clones, there remain vital needs for host developmental mechanisms through which immunity can be amplified or suppressed. The potential need for such mechanisms is best appreciated for cellular immune responses, since the selection and survival of $\mathrm{T}$ cells require recognition of self in the thymus and periphery. Hence, the specificity of $\mathrm{T}$ cells cannot constitute the exclusive mechanism by which the directionality of an immune response (immunity vs. tolerance) is manifest. Based on seminal studies in humans and later in animals, Suciu-Foca and Cortesini [18] have begun to unravel the means by which the interaction of $\mathrm{T}$ cells and antigen-presenting cells generates the critical decision between immunity and tolerance. The process is an active one, depending at least in part on the function of ILT3, as the authors describe.

Regardless of how immunity may be generated, the alloimmune response represents the most potent cellular and humoral reaction known. Rejection of allografts is reliable enough to have allowed the identification and characterization of the major histocompatibility complex, and the reactions are sufficiently sense-specific enough to accurately map the MHC Class I and Class II loci. Bharat and Mohanakumar [19] review the mechanisms by which allogeneic peptides exert such exquisite specificity and propose approaches by which those peptides might be used to engender allogeneic tolerance. These approaches are more than theoretical, because as Semiletova et al. [20] show, allogeneic peptides can be engineered to modify immune responses to a considerable extent. In this seminal work, one can begin to imagine that some day the clinical immunologist will select a set of peptides, rather than a set of immunosuppressive drugs, to specifically and more safely modify immune responses.

This symposium was designed to address the subject of recognition. Excluded are such subjects as how the activated immune system actually destroys a graft and how a graft can acquire resistance to such destruction. The former subject has been covered extensively in the proceedings of Banff Conferences [21] and in recent reviews [22]. The later subject, acquired resistance of a graft to injury, a condition we call accommodation [23] and which we think represents the most common outcome of clinical transplantation of organs, has been critically reviewed elsewhere [24,25].

\section{References}

1. Landsteiner K. Zur kenntnis der antifermentativen, lytischen und agglutinierenden wirkungen des blutserums und der lymphe. Centralbl F Bakt 1900;29:357-362.

2. Carrel A. Transplantation in mass of the kidneys. J Exp Med 1908;10:98-140.

3. Carrel A. The ultimate result of a double nephrectomy and the replantation of one kidney. J Exp Med 1911;14:124-125.

4. Little CC, Tyzzer EE. Further experimental studies on the inheritance of susceptibility to a transplantable tumor, carcinoma (J.W.A.) of the Japanese Waltzing mouse. Journal of Medical Research 1916;33:393-453.

5. Little CC. The genetics of tissue transplantation in mammals. Cancer Res 1924;8:75-95.

6. Snell, GD.; Stimpfling, JH. Genetics of tissue transplantation. In: Green, EL.; Coleman, DL.; Dagg, CP.; Fuller, JL.; Green, MC.; Kaliss, N.; Russell, ES.; Staats, J.; Fahey, EU., editors. Biology of the Laboratory Mouse. Dover Publications, Inc; New York: 1968. p. 457-491.

7. Gorer PA. The antigenic basis of tumour transplantation. J Path Bact 1938;47:231-252.

8. Gibson T, Medawar PB. The fate of skin homografts in man. J Anat 1943;77:299-310. [PubMed: 17104936] 
9. Ehrlich, P.; Morgenroth, J. On hæmolysins. Third communication. In: Himmelweit, F., editor. The Collected Papers of Paul Ehrlich. Pergamon; London: 1957. p. 205-212.

10. Samstein B. Choosing between immunity and tolerance after transplantation. Cell Immunol. (In Press)

11. Cascalho M, Platt JL. Basic mechanisms of humoral rejection. Pediatr Transpl 2005;9:9-16.

12. Huang Y, Rabb H, Womer KL. Ischemia-reperfusion and immediate T cell responses. Cell Immunol. (in press)

13. Medawar PB. Some immunological and endocrinological problems raised by the evolution of viviparity in vertebrates. Symp Soc Exp Biol 1954;7:320-338.

14. Burnet FM, Stone JD, Edney M. The failure of antibody production in the chick embryo. Aust J Exp Biol Med Sci 1950;28:291-297. [PubMed: 14772171]

15. Billingham RE, Brent L, Medawar PB. Actively acquired tolerance of foreign cells. Nature 1953;172:603. [PubMed: 13099277]

16. Koch CA, Platt JL. T cell recognition and immunity in the fetus and mother. Cell Immunol. in press

17. Wasowska BA, Chih-Yuan L, Halushka MK, Baldwin WM III. New concepts of complement in allorecognition and graft rejection. Cell Immunol. in press

18. Suciu-Foca N, Cortesini R. Central Role of ILT3 in the T Suppressor Cell Cascade. Cell Immunol. (in press)

19. Bharat A, Mohanakumar T. Allopeptides and the Alloimmune Response. Cell Immunol. (in press)

20. Semiletova NV, Shen XD, Feldman DM, Gao F, Mhoyan A, Liu D, Busuttil RW, Kupiec-Weglinski JW, Ghobrial RM. Class I MHC allochimeric presentation of composite immunogenic and self epitopes induces tolerance to genetically diverse rat strains. Cell Immunol. (in press)

21. Solez K, Colvin RB, Racusen LC, Sis B, Halloran PF, Birk PE, Campbell PM, Cascalho M, Collins AB, Demetris AJ, Drachenberg CB, Gibson IW, Grimm PC, Haas M, Lerut E, Liapis H, Mannon RB, Marcus PB, Mengel M, Mihatsch MJ, Nankivell BJ, Nickeleit V, Papadimitriou JC, Platt JL, Randhawa P, Roberts I, Salinas-Madrigal L, Salomon DR, Seron D, Sheaff M, Weening JJ. Banff ' 05 meeting report: differential diagnosis of chronic allograft injury and elimination of chronic allograft nephropathy ('CAN'). Am J Transplant 2007;7:518-526. [PubMed: 17352710]

22. Racusen LC, Haas M. Antibody-mediated rejection in renal allografts: lessons from pathology. Clin J Am Soc Nephrol 2006;1:415-420. [PubMed: 17699240]

23. Platt JL, Vercellotti GM, Dalmasso AP, Matas AJ, Bolman RM, Najarian JS, Bach FH. Transplantation of discordant xenografts: a review of progress. Immunol Today 1990;11:450-456. [PubMed: 2073317]

24. Koch CA, Khalpey ZI, Platt JL. Accommodation: preventing injury in transplantation and disease. J Immunol 2004;172:5143-5148. [PubMed: 15100249]

25. Tang AH, Platt JL. Accommodation of grafts: implications for health and disease. Hum Immunol 2007;68:645-651. [PubMed: 17678718] 